\title{
De Horacios y Curiacios: la Alegoría a la muerte de Bolívar en el Perú de las primeras décadas republicanas*
}

\section{From Horacios y Curiacios: the Allegory of Bolivar's Death in Peru in the First Republican Decades}

Irma Barriga Calle ${ }^{1}$

Pontificia Universidad Católica del Perú

Si la imaginería nacionalista se preocupa tanto por ellas [muerte e inmortalidad] esto sugiere una fuerte afinidad con imaginerias religiosas.

Benedict Anderson

* Quiero agradecer a Luis E. Wuffarden y a Ricardo Kusunoki, quienes me apoyaron con información y fueron pacientes con mis divagaciones. También agradezco a Moisés Cueva, quien me ayudó en el acopio de información; a Enrique Quispe del MNAAHP, solícito hasta en tiempos de pandemia, al igual que a Daniel Giannoni y Heidi Hoefken.

Magíster en Historia por la Pontificia Universidad Católica del Perú y miembro asociada del Instituto Riva-Agüero de la misma universidad. Sus temas de investigación se centran en la historia cultural y del arte, fundamentalmente de los siglos XVI, XVII y XVIII. Ha publicado Patrocinio, monarquía y poder: el glorioso patriarca señor san Joseph en el Perú virreinal (2010), así como artículos en diversas revistas y libros enfocados de manera especial en el tema de la muerte, la espiritualidad y la sensibilidad del Barroco. Actualmente, ejerce la docencia en la Maestría de Historia del Arte y Curaduría de la PUCP. Correo: irmabarrigac@gmail. com. ORCID: 0000-0002-3890-7180 


\section{Resumen}

La pugna política adoptó diversas formas en la independencia, y la iconografía fue una de las más relevantes. Aunque se asumió que el nuevo lenguaje artístico debía ser el neoclásico, su puesta en práctica no estuvo exenta de dificultades, y los modelos coloniales persistieron tanto por la carencia de academia como por su valor persuasivo. A través del análisis de la pieza Alegoría a la muerte de Bolivar, el presente artículo explora cómo se produce esta pugna en un tema elaborado para glorificar al héroe y enmendar la imagen desfavorable que se tenía del político en el Perú al momento de su partida.

Palabras clave: Perú, siglo XIX, Simón Bolívar, muerte, guerra iconográfica

\section{Abstract}

The political struggle took various forms during Independence, and the iconography was one of the most relevant ones. Although it was assumed that the neoclassical language should be the new language, this was not easy, and persistent colonial models remained, both by the lack of an Academy, and by its persuasive value. By analyzing Alegoría a la muerte de Bolivar (Allegory of Bolivar's death), this article explores how this occurs in a painting made to glorify the hero and amend the unfavorable image that politicians had in Peru at the time of his death.

Key Words: Peru, XIX century, Simón Bolívar, death, Iconographic War 


\section{Introducción}

El padre yergue las tres espadas y los jóvenes levantan sus manos para consagrar un juramento que los conducirá a la lucha por la patria, mientras las mujeres de la familia, contritas, pero a la vez resignadas, no pueden menos que lamentar por anticipado la tragedia que sobrevendrá. El lienzo de Jacques Louis David, El juramento de los Horacios, de 1784, realizado a pedido de Luis XVI y basado en la tragedia de Pierre Corneille de 1640 -quien, a su vez, había tomado como fuente las Décadas, de Tito Livio-, mostraba en su gran formato no solo la gestación de un estilo, sino también una manera distinta de enfrentar la política, la muerte, la noción de patria y del deber, y el rol que le cabía asumir al arte en todo ello. Frente al deber del bien común, los sentimientos amorosos y fraternales serían dejados de lado, y se alcanzaría una muerte "maravillosa", edificante, que no daría lugar a lágrimas. Poco más de veinte años después, en 1805, Simón Bolívar hacía otro juramento, el del Monte Sacro en Roma, en el cual, apelando a las grandezas y miserias de la antigüedad romana, aludió a los Gracos, a los Horacios, y se comprometió a luchar por la libertad de América. Era un hombre ilustrado y fuertemente marcado por su experiencia en Europa y se sabe que, en San Pedro Alejandrino, donde murió, contaba con once volúmenes del teatro de Corneille, en edición de Voltaire (Sociedad Bolivariana de Venezuela, 1964, p. 389).

En la América independentista, se enarbolaban nuevos ideales y, en este tránsito, las virtudes adscritas a la antigüedad y a la república se veían con los ojos de quienes debían romper con la retórica visual del Antiguo Régimen; sin embargo, dar la espalda a los modelos coloniales, tan arraigados y de valor persuasivo, no era fácil. Se requería de nuevos Horacios y, en ello, un punto crucial era el de la muerte por la patria. Los discursos en torno a la muerte se hallaban en transformación, como lo estaba la sociedad en su conjunto, en un contexto en 
el que no solo las epidemias diezmaban a la población, sino también el hambre y la guerra. Abundante documentación permite seguir este proceso; Susy Sánchez ha estudiado "el papel neurálgico de la guerra como generador de hambre y epidemias" y a Lima, en tanto "ciudad agonizante" cuando entró San Martín, quien habría preferido "asfixiarla" antes que enfrentar directamente a las fuerzas realistas (Sánchez, 2001 y 2015). Ha visto, así mismo, el asedio al Callao por parte de Bolívar con toda su crudeza y considera que recién en 1826 empezó la recuperación (2001, p. 262). Carlota Casalino, por su parte, ha hecho un detallado análisis de diferentes aspectos de la muerte en Lima en el siglo XIX, sobre todo entre los ańos 1840 y 1860 (1999). Dedicó su atención, también, a un tema que, en el bicentenario, resulta de actualidad: la creación del Estado nación y el rol de los héroes en este proceso $(2008,2016)$. La literatura y los estudios sobre el Libertador Bolívar, por otro lado, han sido prolíficos y sería ocioso intentar enumerarlos. ${ }^{2}$ La historia del arte, a su vez, ha analizado, en los trabajos de Natalia Majluf y Luis Eduardo Wuffarden, los avatares del arte en esos años, la generación de aquellos símbolos destinados a sustituir a los anteriores, como también el rol de la pintura en todo este proceso y la "guerra iconográfica" desplegada.

Ante este estado de cosas y por la importante función didáctica de la pintura -pero también por el rol que le cabe en la guerra iconográfica que se da en diferentes ámbitos-, el presente 256 artículo explora la sensibilidad durante el período en torno a la muerte a partir de dos lienzos que comparten, si bien con algunas variantes de importancia, una misma concepción y tema: la Alegoría a la muerte de Bolivar. El de menor tamaño está firmado por el pintor quiteño José Yáñez y fechado en

2 Sobre lo iconográfico, véanse los clásicos trabajos de Boulton (1956) y Arocha (1943). Para una revisión del tema, véase Vanegas (2012). 
1834, es decir, cuatro ańos después del fallecimiento del Libertador, acaecido el 17 de diciembre de 1830 en Santa Marta, Colombia. A su vez, Majluf y Wuffarden han atribuido al otro lienzo el mismo autor y la misma datación, debido a su estrecha relación con la obra anterior. Ciertamente, la autoría de Yáñez es evidente, aunque cabe señalar que las dimensiones y la ambición compositiva de la segunda pintura son mayores. ${ }^{3}$ Ambos cuadros debían mostrar una "bella muerte", la del héroe y padre de la patria, en el período denominado por Jorge Basadre como "determinación de la nacionalidad"; en lo artístico, el paso previo al "cambio y ruptura solo comparable a la conquista" que arguye Majluf (s. f., p. 2) se dio a mediados de dicha centuria. Se considera que, al haber tenido la preocupación por la muerte en el Antiguo Régimen un lugar primordial, la adecuación a los nuevos tiempos fue un proceso arduo, engorroso y problemático, que se puede percibir en esta iconografía, y que, a pesar de la anunciada ruptura con la cultura y el arte anteriores, las persistencias de los modelos coloniales fueron manifiestas. Al escrutar estos temas, se espera contribuir a una mejor comprensión de la sociedad peruana en tránsito, compleja y, no pocas veces, contradictoria.

\section{Yacente a las puertas de la gloria}

Las representaciones de la muerte del Libertador no son pocas, pero suelen ser muy posteriores y de un tenor distinto

3 Ambos lienzos se encuentran en el Museo Nacional de Arqueología, Antropología e Historia del Perú; para el de mayor formato, se indica el rango temporal amplio del siglo XIX y no hace la atribución mencionada, por lo que se ha respetado la leyenda que el museo proporciona. No se conoce cuándo ingresaron en el museo. Ricardo Kusunoki (comunicación personal) se inclina a pensar que debió ser al abrir el Museo Bolivariano, en Magdalena, en 1924. Podría ser, también, cuando se creó la Sociedad Bolivariana como entidad oficial en 1927 o en el centenario de la muerte de Bolívar. 
al del lienzo que nos ocupa. Vale la pena, en ese sentido, hacer mención a alguna de ellas, que permitirá establecer la diferencia. Muerte del Libertador (1883), de Antonio Herrera Toro, por ejemplo, que muestra la asistencia espiritual a Bolívar, no pertenece al ámbito de la alegoría, sino que es claramente una pintura de historia, en la cual se presentan como eventos simultáneos dos momentos distintos. Bolívar, al centro de la composición, sedente en su lecho, cabizbajo, resignado y al parecer algo frustrado, mira en sentido contrario al ritual que el sacerdote realiza. El cuadro Coronación de la Virgen por la Santísima Trinidad, colocada en la pared principal, pretendería acentuar -aunque vanamentela religiosidad del acto, que parece no interesar mayormente a su protagonista. ${ }^{4} \mathrm{El}$ médico, Alejandro Próspero Révérend, a su lado, le toma la mano, y mira de frente y apenado al espectador. Un grupo de militares asiste al acto: el más cercano a Bolívar baja la cabeza tristemente, mientras uno vuelve su rostro para incorporar al público y dejar en claro su presencia en tal acontecimiento; otro, notoriamente conmovido, se cubre los ojos y parece querer abandonar la habitación para no presenciar lo que sucederá. Solo una persona viste de civil; se puede presumir que se trata del dueño de la Quinta de San Pedro Alejandrino, Joaquín Mier. La pintura constituye, así, un registro pormenorizado del hecho, realizado poco más de cincuenta años después, y ya con un aura romántica. Las pinturas del Museo Nacional de Arqueología, Antropología e Historia del Perú -donde se encuentran las dos imágenes que analizaremos- presentan otro cariz. Son representaciones del hombre ilustre que moría de causas naturales, pero cuya muerte se constituía en una partida grandilocuente y propagandística que debía

4 Bolívar no era una persona religiosa, sino pragmática y consciente de la importancia de la religión en el proceso de constitución de una nueva sociedad americana (Lynch, 2019, p. 49). 
exaltar los ánimos, en la línea de los Horacios de David. ${ }^{5}$ Así, en comparación con otras pinturas, como la descrita, en las que se ve al Libertador en su lecho de muerte y en un entorno realista -incluso es posible identificar a los personajes presentes-, muestran la glorificación del personaje, que, con traje militar, se halla sobre un ataúd.

En todo caso, el tiempo en el que se ejecuta este par de lienzos difiere notoriamente de aquel en el que trabajaron artistas como Herrera, José María Espinosa o Daniel Hernández, cuando primaba el afán de hacer una narrativa que diera lugar a un discurso nacional. Para esos años -subraya Majluf (2018)-, fue evidente la falta de interés en plasmar los sucesos históricos y el acusado afán en la pintura de retrato y en el uso de la alegoría para referir a hechos fundacionales. Esta había pervivido a lo largo de los años y en la Revolución francesa había desempeñado un relevante papel para sugerir una suerte de continuidad con la Antigüedad clásica. Pero, además, la alegoría tenía la cualidad de ser una suerte de "solución religiosa”, pues imponía obediencia a verdades que no admitían matices y que desvalorizaban al oponente (Reyero, 2010, p. 71). En este caso, presentaba la ventaja adicional de evitar afrontar un tema espinoso para la república criolla: el del indio y la posibilidad de un levantamiento indígena. ${ }^{6}$ El romanticismo llegaba en esos ańos, pero no se dirigía a la historia, sino a la tradición y al costumbrismo. En este contexto, entonces, se rescata su singularidad, al ser estos de los pocos lienzos del período que abordan un tema histórico co-

5 Ver Torres (2001, p.73), que contrapone la muerte del héroe en David y en Goya.

6 El temor se había visto potenciado con el movimiento de Túpac Amaru II. En 1821 se percibe en la comunicación del marqués de Montemira a San Martín cuando este va a hacer su entrada a Lima. (Tauro, 1973, p.230). La negación de la historia ha sido analizada por Majluf (1994, p.32). 
etáneo. ${ }^{7}$ Sin embargo, la alegoría está presente para refrendar la muerte gloriosa.

La muerte real de Simón Bolívar había distado largamente de ser memorable. Aquejado de antiguo por una severa tuberculosis mal cuidada y en una situación adversa en lo político - pues Venezuela condicionó los tratos con Nueva Granada a su expulsión-, debió planificar su retiro a Europa previo paso por Jamaica. Había llegado a Santa Marta el $1 .^{\circ}$ de diciembre de 1830 y, a causa de su estado, hubo de ser conducido en una silla de manos. Quedó instalado por unos días en las oficinas de aduana hasta pasar a la Quinta de San Pedro Alejandrino el día 6, por invitación del hacendado Joaquín de Mier. Allí, Révérend desempeñó un rol clave por cuidar del enfermo, y también por llevar un diario en el que registró pormenorizadamente lo que acontecía con el enfermo, sus males y los remedios aplicados en un intento de evitar lo que él vio como un inminente final.

Por él, podemos saber que "disimulaba sus padecimientos", que empezó a delirar el día 8 de diciembre, que a los dos días hizo testamento y puso en orden sus asuntos temporales, y que se llevaron a cabo los espirituales con el obispo José María Estévez. Así mismo, el galeno incide en la "confusión en las ideas y aberración de la memoria" observadas desde el día 13 y cómo la "lucha extrema de la vida con la muerte", que se dio desde el 16, acabó con el triunfo de la segunda el día 17. Esta fue la muerte real, concreta, del Libertador: no había sido en batalla, heroica y triunfal; tampoco producto de una ejecución o asesinato, ni al final de una larga y próspera vida plena en honores y coronada por una serena y edificante muerte. Se trataba, más bien, de una muerte prosaica, a pesar de la encendida y emo-

7 Majluf y Wuffarden se ocupan del cuadro en "Entre la ruptura y la continuidad" (2004, p. 102) y en "El siglo XIX: entre tradición y modernidad" (2015, p. 12). 
cionada proclama que él mismo leyó hasta que las fuerzas le respondieron, justo una semana antes de morir. ${ }^{8}$ Este discurso, dirigido a los colombianos, junto con su testamento, mostraría la vena del líder. Sin embargo, para la fijación en la memoria, se requería modelar la muerte del personaje, como también su actuación. La composición alegórica de Yánez debía contribuir a gestar la imagen heroica del Libertador.

Yáñez ideó una escena que adquiere su desarrollo más complejo en el lienzo más grande. Muestra al protagonista yacente, encima del cajón, sobre un piso ajedrezado, mientras un rompimiento de gloria invade la habitación. A la derecha, tres militares: uno, erguido y con los brazos cruzados, contempla resignadamente al difunto, mientras otro, sedente y completamente agobiado por la pena, apoya tristemente la cabeza en su mano derecha; el tercero hace guardia. Puede creerse que el primero de los nombrados es el comandante general Mariano Montilla (1782-1851), muy cercano a Bolívar, presente cuando murió y de quien se dice que detuvo el reloj tres minutos después del fallecimiento. Hay motivos para suponer que el desolado general, sentado también, es José L. Silva (17911873), amigo personal del Libertador, esposo de su sobrina y quien habría proporcionado la camisa que se dice entregaron al médico para que le colocara como mortaja para reemplazar aquella rasgada (Révérend, 1866, pp. 36-37). Dichos militares estuvieron presentes durante la autopsia que, a las horas del fallecimiento, realizó el galeno; fueron testigos del testamento, y el segundo también albacea. El tercer personaje, en traje de húsar y en guardia ante el difunto, podría ser Belford Wilson, edecán a quien se refirió agradecidamente Bolívar en dicho documento, y presente en el óbito, aunque no se descarta que sea el capitán Andrés Ibarra, registrado como edecán en la "Proclama” del 10 de diciembre (Révérend, 1866, pp. 51-2).

8 "El Libertador a los colombianos". En Révérend (1866, pp. 58-60). 
Detrás de esta escena de carácter realista, se observa el horizonte durante el ocaso, en referencia al encendido anuncio del 21 de diciembre de que el Sol de Colombia había muerto. ${ }^{9} \mathrm{Al}$ pie del féretro, una escena de dolor se desarrolla. Tres jóvenes mujeres de torso desnudo y delicados cintillos en la cabeza con los colores de Ecuador, Venezuela y Colombia, arrodilladas, sostienen a una matrona desfalleciente, que viste faldellín de plumas, porta una corona de laurel en la cabeza y muestra el carcaj a los pies: la alegoría de América. ${ }^{10} \mathrm{Al}$ pie de ellas, se asoma la cornucopia de la abundancia y dos banderas caídas que cubren en parte lo que parecen ser balas de cañón. A la cabeza del féretro, sobre nubes y de notorio mayor tamańo que las jóvenes, puede verse a un personaje masculino sedente con la bandera peruana, mientras una figura femenina lleva la boliviana, ambos con actitud melancólica.

La escena de las mujeres al pie de Bolívar es intensamente iluminada por un fulgor que proviene del ángulo superior izquierdo, donde se ve un templete a modo de morada de los dioses o empíreo, en cuya dirección avanzan dos putti que cargan palmas de victoria; casi al pie del templo, otros dos putti: uno sostine la pica con el gorro frigio y otro, una corona de laurel. En el extremo superior opuesto, el izquierdo, y siempre en el rompimiento de gloria, se advierten algunos personajes de la mitología clásica: las tres parcas -Cloto y su huso; Láquesis, en escorzo, quien mira a sus contrapartes, y Átropos, quien alista sus tijeras-. Apenas más arriba, se percibe al Tiempo con la guadańa; un poco más abajo de las parcas, un personaje que puede interpretarse como la mala

9 "El General Comandante de Armas de la Plaza y Provincia a las tropas que la guarnecen", 21 de diciembre 1830. En Révérend (1866, p. 67).

10 Aunque hay representaciones tempranas que resignifican la alegoría de América, y estados como Cartagena que la asumen, estas llevan normalmente la granada en la mano. No la hemos encontrado para el caso de la Gran Colombia. Véase Chicangana-Bayona (2010). 
fama, pues lleva un manto negro y rasgos desagradables en el rostro (Vaquero, 2018, p. 125), quien se encuentra tocando la trompeta dirigida hacia la escena terrena. A este personaje le da la espalda una alegoría que puede identificarse con la Historia, ${ }^{11}$ la cual, coronada de laurel, observa en sentido opuesto de las parcas y el Tiempo. Mira hacia adelante; sentada, reposa su brazo izquierdo en una pequeña pilastra o pedestal en cuyas distintas caras se leen las victorias bolivarianas. Procede a escribir, en un indestructible libro pétreo, el nombre de Bolivar. Tres putti la rodean: uno exhibe cartela con las inscripciones de Bogotá, Guayaquil y Quito; otro sujeta el libro y una corona de laurel encima de este, mientras contempla al espectador; el tercero lleva un manojo de palmas a repartir. Al lado, se encuentra un personaje que adquiere notoria importancia: el mariscal Sucre, quien porta en su mano izquierda su espada que, además de indicar su calidad militar, refiere a la idea de justicia. ${ }^{12}$ Había sido asesinado el 4 de junio de 1830, es decir, seis meses antes de la muerte de Bolívar. Yáńez lo había retratado. ${ }^{13}$ No resultaba gratuita su presencia, dado su rol protagónico en la consecución de la independencia, la cercanía entre ambos personajes y la admiración que Bolívar le manifestó cuando elogió su "ejecución divina" en la batalla de Ayacucho. ${ }^{14}$

11 Podría identificarse también con la Gloria, como consideran Vidal, Quispe y Véliz (2015, p. 193).

12 No puede dejarse de pensar en la imagen de Cristo juez que contempla desde el cielo a la humanidad para hacer justicia. En el caso del lienzo pequeño solo se ve la empuñadura de la espada, pero la justicia está representada por el putti que ayuda a sostener el libro de la historia y que lleva una balanza en la mano. Puede tener que ver con la justicia que la historia haría a Bolívar, pero también alude al clásico pesaje de las almas.

13 Se jacta de haberlo hecho de memoria. El Comercio, 22 de abril de 1843.

14 Ver Carta de Bolívar a Sucre, Lima, 21 de febrero de 1825 (Bolívar, s. f., pp.31-32). 
Sucre, cual atleta de la Antigüedad, apenas cubierto y como parte del grupo alegórico de la Historia, tiene la mirada gacha, hacia la escena de la habitación de Bolívar, y señala el camino hacia el templete. Entre su persona y lo que parece el Olimpo, se observa un conjunto de personas desnudas, algunas de las cuales ya cuentan con la palma de martirio y victoria. La asociación entre valores clásicos y republicanos se evidencia nítidamente, y los ilustrados patriotas hacían de estos recintos -el Olimpo y los Campos Elíseos- espacios adecuados para debatir sobre injusticia, dominación y soberanía. ${ }^{15}$

Los personajes representados encima de Sucre, en la zona central y superior del cuadro, son bastante tenues, casi inmateriales. Vale seńalar que, en el otro lienzo, el firmado por Yánez, los personajes están con la vestimenta de la época y, a pesar de que se percibe claramente a un clérigo y a algunos civiles, son los militares quienes destacan y la figura de Sucre lo subraya. La invitación a continuar sus pasos es más explícita aún: la muerte por la patria conducía a la superación de la muerte a través de la gloria. La pintura se convierte en una exaltación del estamento militar, mientras, en el otro caso, el hecho de que los personajes estén desnudos acentúa el sentido alegórico, lo que transmite un mensaje de carácter más abierto, un llamado general a los altos ideales.

Sin embargo, no es el único matiz que puede observarse al comparar ambos cuadros. El contraste entre la luz que emana del cielo y el lúgubre recinto en que se encuentra el cadáver es mucho más acentuado en el lienzo de pequeño formato; igualmente, la escena del horizonte es crepuscular en el grande, mientras, en el otro, es la oscuridad la que predomina. A su

15 En "Diálogo de Atahualpa y Fernando VII en los Campos Elíseos" (Monteagudo, 1974, p. 254), el Inca afirmaba que la "base y único y firme sustentáculo" de la soberanía era "la libre, espontánea y deliberada voluntad de los pueblos". 
vez, la alegoría de América se torna en la de la Gran Colombia en el más pequeńo, porque la mujer está vestida con sus colores y a su espalda se observa una bandera de dicho país, caída. Quienes ayudan a que no desmaye son, en lugar de las jóvenes, tres niñas, pudorosamente ataviadas. Por otra parte, hay una diferencia en los personajes alegóricos que contemplan melancólicamente la muerte del héroe: en el lienzo de formato menor, se ha seguido la representación tradicional de los tocados de plumas en la cabeza, mientras el otro los muestra con la borla en la cabeza; es decir, es una representación más "histórica”. Por lo dicho, cabría pensar que el primero, por su tamaño y acento militar, fue pintado para la sala de algún caudillo militar del período, mientras el segundo, para ser exhibido en alguna institución pública, por lo que debía estar más acorde con los aires de modernidad y apego a la Antigüedad clásica, considerada en esos años como lo "civilizado".

Conviene destacar que, en ambas pinturas, se ha intentado acentuar el sentido laico, secular, de la muerte. No se trata de una muerte que pase por la intermediación de la Iglesia, pues no se ve a los ministros religiosos ni la administración de sacramentos. Sin embargo, a pesar de darse un sentido que busca prescindir de lo religioso, el sentido apoteósico del Barroco está presente (Majluf y Wuffarden, 2015, p.12) y el rompimiento de gloria no puede menos que hacer pensar en el cielo agitado desde donde sus habitantes observaban el lecho del agonizante y el juicio particular de su alma. ${ }^{16}$

Por otra parte, las personas allegadas a Bolívar, y él mismo, se encargaron de incidir en el martirio que había vivido al ser in-

16 Compárese la obra con El rey Amadeo visitando el cadáver del general Prim (ca. 1875, Museo de Historia, Madrid) de A. Gisbert: el acto transcurre en la basílica de Nuestra Señora de Atocha, y se ve eclesiásticos acercándose, pero la escena es secular; la ceremonia religiosa que se avecina parece meramente protocolar. 
comprendido, perseguido, calumniado y conducido -aseveraba él- "a las puertas del sepulcro", a donde decía estar dispuesto a descender por la consolidación y "felicidad de la patria". ${ }^{17}$ Pero también estaba el detalle de la camisa raída que, se decía, tenía para ser enterrado, lo cual apuntaba a su pobreza y austeridad, a la idea del sublime sacrificio por el ideal que lo hizo abandonar el cuidado de su salud. Todo esto podía abonar a una suerte de santidad del Libertador, que Yáñez insinúa con la palma de la victoria de los mártires y la corona de laurel con que se premiaba a los vencedores olímpicos, pero también a las figuras de santidad al alcanzar el cielo. Lo sagrado y lo secular pasan a confundirse, a borrar sus fronteras. ${ }^{18}$

No era la primera vez que Bolívar era motivo de una representación alegórica, pues él fue la imagen del héroe por excelencia de la independencia en los primeros ańos. Evidentemente, tomó la de Bonaparte como modelo. ${ }^{19} \mathrm{La}$ parafernalia que lo rodeó, la pompa y el boato lo habrían embrujado. En el llamado "Día del Triunfo" (18 de setiembre de 1819), cuando fue recibido en Bogotá, le ciñeron la corona de laurel y colocaron bajo dosel un lienzo mandado realizar para la ocasión que supuso, paradójicamente, borrar un retrato previo (se ha sugerido el de Fernando VII o el de Pablo Morillo). Aclamaciones y vivas acompañaron al Libertador en un episodio por demás trascendente para su imagen de ícono de la independencia. En el Perú, a su vez, fue recibido con tremenda expectativa y celebrado en términos alegóricos y clásicos. ${ }^{20} \mathrm{Si}$ los libertadores habían inaugurado un tiempo

17 "Ultima proclama del Libertador". En Itinerario, 1951, pp. 49-50.

18 Sucedió en Francia con sus "mártires por la revolución" (Soboul, 1975, p.264).

19 No en vano la cuadra de la quinta de Magdalena lucía un retrato del corso (O'Phelan, 2015, p.32).

20 Véase el grabado que Marcelo Cabello realizó de la pintura (Majluf y Wuffarden, 2015, pp. 68-69). 
nuevo, se requería romper con el remanente de lo "gótico", e imponer un arte diferente y racional; el régimen republicano necesitaba de artistas que lo hicieran. Resultaba un imperativo. La pintura de Yáñez se debe comprender en ese contexto.

\section{Pinceles nuevos, antiguos y persistentes}

Si tan pronto como el 22 de agosto de 1821 San Martín hizo convocar a literatos y "profesores y aficionados de nobles artes" para erigir un monumento que perpetuara la memoria de quienes trabajaron "por romper las cadenas", era por su plena consciencia de la necesidad de crear una nueva civilidad y del rol de las artes en ello. Se trataba, entonces, de crear una maquinaria que marcara la ruptura con aquella cultura en la que la "densa atmósfera no permitía la penetración de las luces” (De la Puente, 1974, pp. 295 y 500).

La pintura, en este sentido, era dada no solo a trasmitir contenidos y formas, sino a jugar un rol de primera línea en la "guerra iconográfica”, que no era de reciente data. En esta guerra, se pedía asumir otro lenguaje, tarea que, de ninguna manera, sería sencilla. Puede decirse que fue un período complejo, "impreciso en lo artístico" (Kusunoki, 2006, p. 184) y pleno en "hibridaciones", que se habían venido dando anteriormente en la pintura limeña (Wuffarden, 2006). En este estado de cosas fue que pintores como Yáñez debieron actuar.

José A. Yáñez, pintor quiteño, llegó al Perú en los años treinta, y se sabe que, a fines de 1834, salió, para regresar al país en 1841, donde murió en 1860 (Majluf, 2015, pp. 291-300). Escribió obras de teatro, ${ }^{21}$ un manual de dibujo y anunciaba tener un manuscrito sobre las Bellas Artes en el Ecuador. ${ }^{22}$

21 Se le conoce El Insurgente, Huayna Cápac (Vallejo, 2011, p. 156), La aurora de la Independencia (Holguín, 1998, p. 300).

22 El Comercio, 22 de abril de 1843, p. 5. Sostuvo en esas páginas una agria 
Estuvo dedicado principalmente al género del retrato, que contribuía a cimentar el lugar de las élites republicanas y el nuevo sistema político -y atraía por su afán de mímesis que equivalía a modernidad-, pero también por ser una manera acercarse a la historia que no implicaba una narrativa nacional (Majluf, 2018 y 2014, p. 9). Ante este mercado, no pocos pintores quiteños llegaron al Perú.

Yáñez hacía retrato "al óleo y en miniatura", incluso "de memoria”, y en los diarios locales ofrecía enseñar "geometría, óptica y anatomía". Debe tenerse en cuenta, no obstante, que la pintura colonial, en la cual fue formado este pintor, no había tenido entre sus preocupaciones centrales el estudio sistemático del cuerpo humano. $\mathrm{Y}$, en un medio en el que se carecía de modelos de yeso para el aprendizaje, un arte que pretendiera imitar la Antigüedad clásica representaba un reto evidente. ${ }^{23}$ Pasar de pintar retratos a composiciones complejas con muchos personajes y en movimiento, en los que aspectos como detalles de texturas, colores, etcétera, relevantes en un retrato, dejaban de serlo, requería de un proceso de aprendizaje y adecuación por parte de los pintores. Procesar los cambios de género pictórico, pretender ser académico sin academia ante la necesidad de ser "moderno" y romper con el arte anterior -cuando en Quito los modelos coloniales habían tenido un manifiesto éxito comercial- no era fácil. Tomar un hecho histórico y darle un cariz glorioso, tampoco.

Cabe preguntar por qué se escogió a Yánéz para dicho encargo y por qué, en 1834, se habría considerado conveniente pin-

disputa con otro pintor quiteño, lo que significa que fue un personaje notorio en la ciudad de Lima.

23 Majluf (1993) perfila el panorama de un pintor de esos años: no solo era "artista sin público", sino que su obra no se insertaba en contexto estilístico o de reflexión estética alguna. Kusunoki (2010, p.52) vio que a fines del siglo XVIII se había perdido la conexión entre intelectualidad y pintores. 
tar la muerte de Bolívar. Cabe recordar que Francis Martin Drexel, quien había retratado a Bolívar y trajo nuevos aires a la pintura local, ya no estaba en el Perú. Antonio de Meucci, exitoso retratista en miniatura, había hecho varias versiones sobre marfil del Libertador, en las cuales se percibían los efectos de la mortal enfermedad. Quien parecería ser de alguna manera la opción más evidente para realizar el tema era José Gil de Castro, aún activo en Lima y principal propulsor del ícono bolivariano. Aunque para entonces se ha destacado un cierto desplazamiento de su figura, posiblemente el mismo año retrató a Mariano Alejo Álvarez y su hijo (Museo de Arte de Lima, MALI), y aún pintaría a Salaverry y a Luis José de Orbegoso. Existiría, sin embargo, una razón política tras la decisión de no escogerlo, si se recuerda que Kusunoki y Wuffarden han llamado la atención sobre lo que han denominado su "ciclo antibolivariano", en el cual satisfizo encargos de las distintas personalidades que se habían visto perjudicadas, atacadas y perseguidas por la política del Libertador. ${ }^{24}$ Estaba profundamente inmerso en la "guerra iconográfica" de su tiempo, como siempre lo había estado. No parecía, entonces, la figura más adecuada para reivindicar la imagen de Bolívar. Sí podía serlo, en cambio, un pintor procedente de un país presidido por Juan José Flores, lugarteniente de Bolívar y muy cercano al mariscal Sucre, formado en la tradición colonial, y que, por lo tanto, no resultaba tan innovador como para que el mensaje no tuviera llegada ni tan realista como para dejar de ennoblecer al modelo. Además, ya había retratado a Sucre y a Bolívar ${ }^{25}$. Yáñez se presentaba así, como una muy buena opción.

24 Para profundizar en estos temas, son imprescindibles los trabajos de Wuffarden, Majluf y Kusunoki. Véase Wuffarden (2001), Majluf (2014, p. 16), y Kusunoki y Wuffarden (2014, p. 48).

25 Ambos retratos fueron realizados en 1831, cuando estos líderes ya habían fallecido. Agradezco a Wuffarden y Kusunoki la información sobre el cuadro de Bolívar. 
En 1834, la percepción que sobre Bolívar se tenía no era la misma que al tiempo de su salida del país, de su proclama contra el Perú y de la guerra con la Gran Colombia. Mucha agua había corrido bajo el puente en poco tiempo y la inestabilidad campeaba. Un gobierno fuerte, así fuera autoritario, podía ser visto con cierta nostalgia por algunos, como una alternativa que llevara al ansiado y tan lejano orden. Los liberales habían perdido posiciones y fueron derrocados por Agustín Gamarra, pero la lucha política no cesó y se dio en variados frentes: la prensa, el teatro, el Congreso. Gamarra afrontó múltiples movimientos en su contra y una opinión pública en mucho adversa. Si la efervescencia política estaba a la orden del día, precisamente durante 1834 se intensificó ante el levantamiento del candidato oficialista perdedor, el general Pedro Bermúdez, contra el presidente electo, Luis José de Orbegoso. Esto condujo a la guerra civil, que terminó con el abrazo de Maquinhuayo del 3 de mayo.

Otro acontecimiento relevante tuvo lugar ese año: la promulgación de una nueva Constitución, que, de acuerdo con Basadre (1968, tomo II, p. 85), fue "un minucioso intento de erigir murallas de papel contra el autoritarismo militar". Se dieron, así mismo, decretos que, en principio, afectarían a la casta militar. No por nada el Ejército era para los liberales "centro de disturbios" (Aljovín, 2000, p. 149). La pugna política encontraría otra expresión en la iconografía. Cabe pensar, entonces, que quien se interesara en reivindicar la idea de una mano firme en el gobierno tendría interés en enaltecer a Bolívar, quizá algún militar afectado por la política de los liberales o alguien vinculado con los periódicos La Verdad o El Conciliador, que apoyaron el golpe de Bermúdez; con el Mercurio Peruano; o con las tertulias de José María de Pando, Pardo y Aliaga, o José Joaquín de Mora.

Yáñez pintó el lienzo pequeño y lo firmó en 1834, y ese es el año que se cree pudo haber realizado la alegoría de ma- 
yor formato. Surgen, no obstante, interrogantes cuando se advierten las ligeras, pero quizás significativas, diferencias ya mencionadas entre ambos cuadros; solo como hipótesis, estas permiten especular que, tal vez, el segundo fue realizado cuando regresó Yánez al Perú en 1841 o poco tiempo después. Podría abonar a favor de esta conjetura el hecho de que, en el primero, la presencia de la Gran Colombia tiene mayor fuerza que en el segundo, como si la distancia temporal respecto de su disolución fuera corta. De otro lado, la representación del Perú, al costado de Bolivia, es más "histórica" y cercana a la imagen convencional de un inca, y sugiere una individualidad más acentuada; ello sugiere que podría ser de un período posterior a la Confederación Perú-Boliviana. ¿Quizás de tiempos del movimiento "regenerador" de Vivanco, en 1841, o de su Directorio, en 1843? El año 1841 había sido de extrema convulsión, porque fue también cuando el presidente Gamarra murió en Ingavi. El Directorio, gobierno de ejecutivo fuerte, podría pensarse como un momento adecuado para encargar un lienzo de este tipo, por el cual se contribuía a extaltar al Libertador de los cinco países y se reafirmaba la necesidad de un gobierno que supusiera obediencia y orden ante todo. Se otorgaría, por otro lado, una aureola de magnificencia al héroe en términos más cosmopolitas, y cercanos a lo clásico y a lo racional que en la obra pequeña. ${ }^{26}$ En todo caso, en ambas obras, al mostrarse al héroe próximo a acceder al templete de la inmortalidad y obtener la palma de la victoria, su accionar terreno quedaba validado, pues este le había permitido alcanzar la una y la otra. Con ello, se combatía la imagen desfavorable que Bolívar había dejado en el Perú al momento de su partida y su temprana muerte. No obstante, si era "padre" de la patria para sus partidarios, difícilmente

26 Kusunoki (2009) ha estudiado los tiempos de "tránsito" entre la muerte de Gil de Castro (1837) y la cada vez mayor fuerza del academicismo vinculado a las "naciones civilizadas" y al liberalismo económico. 
habría consenso en ello y en considerar su muerte como la coronación de una vida excelsa. Aún había heridas abiertas.

\section{Héroes, padres y villanos}

Si la "hermana" Marianne y los "mártires" de la revolución debían intentar llenar el vacío dejado por el padre en la descristianizada Francia, en el Perú republicano también se requería de héroes que mostraran la capacidad del martirio y figuras que se constituyeran en modelos de accionar cívico y pudieran hacer de padres de la patria. ${ }^{27}$ Mártir ya había: José Olaya, ejecutado en Lima dos meses antes de la llegada de Bolívar. El Libertador, por su parte, pretendió llenar el vacío del padre, ${ }^{28}$ erguirse como el salvador, el padre protector de la libertad; para sus seguidores, como Benito Laso, era el único capaz de hacerlo. Sin embargo, al irse, en setiembre de 1826, dejó tras de sí una estela de disconformidad. El culto a su persona era endeble y la figura paterna parecía no estar bien representada por él.

No solo la Constitución Vitalicia fue motivo de desencanto. Hubo, de hecho, aspectos que pudieron afectar su imagen, algunos de los cuales no tuvieron que ver directamente con su accionar, sino con la adecuación a la sociedad republicana. Bien se refiere Rizo Patrón a los nobles limeños en tanto "cortesanos atrapados entre el mundo en el que nacieron y el mundo de los nuevos ideales" (2012, p. 311).

272 Por su parte, Bolívar desplegó una política de persecución a personajes que fueron del entorno del poder: Guisse, Neco-

27 Los discursos en esos años se daban en términos de una "historia familiar" (Hunt, 2017, p. 33).

28 De acuerdo con Majluf (2013, pp. 93-103), Bolívar quiso identificarse a sí mismo con el Estado y dar nueva corporeidad al poder, pero no pudo sustituir al monarca, lo que solo fue dable por el escudo y la bandera. 
chea, Luna Pizarro cayeron en desgracia; otros pasaron por las armas. Se condenó por traición a la patria a personalidades como Juan F. de Berindoaga, conde de San Donás y ministro de Guerra en tiempos de Torre Tagle, luego de un juicio discutible. Llovieron los pedidos a su favor, pero Bolívar no accedió. Además, su cuerpo y el de otro ajusticiado fueron expuestos largas horas en la plaza de Armas de Lima en abril de 1826; al final del día, apenas se podía reconocer que eran humanos (Salvin, 1973, p. 74) . En agosto, tuvo lugar otra ejecución plena en patetismo, la de Manuel Aristizábal, quien -se pudo observar- llevaba los colores patrios bajo la casaca. ${ }^{29} \mathrm{El}$ acontecimiento provocó la exaltación, gritería y conmiseración de los espectadores. La relación de Bolívar con la élite se vio fuertemente resquebrajada luego de sucesos como estos. ${ }^{30}$ La severidad extrema y la crueldad eran mal vistas, y, en el pasado, las ejecuciones habían constituido eventos centrales en la vida de las sociedades de antiguo régimen, para las cuales había un conjunto de reglas a ser respetadas; de no serlo, provocaban la movilización de la comunidad. ${ }^{31}$ Con las luchas independentistas, se vieron sustancialmente modificadas. De pronto, el delito de traición ya no afectaba al cuerpo del soberano (Foucault, 2004, p. 35), sino a la patria, un concepto abstracto y complejo que se mostraba

$29 \mathrm{Al}$ ser alcanzado por el primer proyectil, anunció: "Me habéis herido únicamente, tirad a la cabeza", para caer luego abatido (Vargas Ugarte, 1971, p. 41)

30 Esta relación ha sido definida como "fría y distante" (O’Phelan, 2019, p. 15) y este acto podía ser visto como un modo de humillarla y someterla (Basadre, 2015, pp. 115-116).

31 Durante siglos, la prédica religiosa y los tratados del bien morir alentaron, por ejemplo, que se intercediera ante la autoridad por conseguir el perdón del reo, fuera o no culpable. Habían transcurrido casi cien años de la ejecución de Antequera, que mermó la popularidad de los jesuitas y llevó al descrédito de Castelfuerte, pero ¿qué tanto había cambiado la sensibilidad sobre estos temas en esos ańos? 
ambiguo y cambiante, porque quienes habían luchado por la patria acababan muriendo por atentar contra ella.

Respecto de la justicia, los ilustrados esperaban que fuera racional, efectiva y que contribuyera a la felicidad de los pueblos; la justicia como principio rector quedaba atrás. El fin de todo gobierno radicaría en la "felicidad y tranquilidad interiores del Estado" (Romá y Rosell, 1768, p. 316); esto fue enarbolado con fruición por San Martín y por Bolívar, así como por sus seguidores. Baste citar la prensa independentista, el Estatuto Provisorio y la entrada de Bolívar a Bogotá, al son de "Viva el grande Bolívar-viva el Héroe a quien debemos nuestra felicidad-viva el inmortal exército de nuestros libertadores" (Boulton, 1956, p. 44). No obstante, si estos líderes eran esperados como agentes de la felicidad, la realidad que los aguardaba era muy diferente, porque la desolación, el hambre y el caos se impusieron en Lima, que no había sufrido antes los estragos de la guerra. Las enfermedades minaron a una población mal alimentada desde antes de la llegada de San Martín, quien bloqueó la entrada de alimentos, tal como hizo Bolívar cuando se sitió el Callao, de modo que condenó a muerte a quienes abastecieran a los realistas. Se dieron actos de extrema crueldad en el trato al enemigo por ambos lados. ${ }^{32}$ La muerte se veía por todas partes y, en tanto, la deserción, el cambio de bando, el robo y la rapińa estuvieron a la orden del día; la pena capital era muchas veces resultado de juicios sumarios.

Simón Bolívar acabaría sus días proclamando que la clemencia con los criminales era "ataque a la virtud" (Bolívar, 1951

32 Stevenson narra actos de maldad que habría cometido San Martín y excesos de los realistas; también lo hace Salvin, y Thomas refiere la "malignidad y locura de los españoles" al incendiar pueblos y fusilar enfermos. Mathison da cuenta del horror de ver en el cementerio cuerpos abandonados sobre los muros (Stevenson, 1971, pp. 294, 296, 332; Thomas, 2019, pp. 133 y 177; y Mathison, 1971, p. 288). 
[1829], p. 55), y su rigidez e implacabilidad ${ }^{33}$ con los nacionales -al ser él extranjero- no pasaron inadvertidas, más aún cuando parecía no haber ninguna certidumbre absoluta de la cual asirse. Muchos cambios habían sobrevenido desde la llegada de los Libertadores. La estadía de San Martín en el Perú, sin embargo, fue más breve que la de Bolívar y, políticamente, no fue tan lejos. Por lo tanto, ya con una popularidad menoscabada, con muchos enemigos políticos y fuera del Perú, se podría juzgar si Bolívar efectivamente correspondía a la imagen de padre de la patria que se deseaba. El Congreso de 1828 parecía tener claro que no lo era y el patronazgo de san José sobre la república peruana casi es un simbólico reclamo. Olaya y san José eran, de algún modo, arquetipos del patriota dispuesto a sacrificarse y del gobernante deseado. ${ }^{34}$

Resulta revelador que, una vez instalado el Congreso, lo primero que hizo fue leer un mensaje de San Martín. ${ }^{35}$ Sin embargo, hubo otro acto significativo que resalta Majluf: el retrato de Bolívar fue reemplazado en el Supremo Tribunal de Justicia de Lima por una pintura del escudo nacional, realizada por Gil de Castro; con ello, se terminaba de "ajustar los términos simbólicos de la revolución republicana” (2013, p. 105). Lo iconográfico desempeñaba, por lo tanto, un rol clave y reconocido. En este contexto, desfavorable a su pro-

33 Ya se había manifestado con la muerte en Angostura de Manuel Piar (16 de octubre de 1817) por "deserción, rebelión y traición". Poco antes, este era el "caudillo venezolano más exitoso" (Sáez, 2013, p. 87).

34 Majluf y Wuffarden subrayan la "asociación simbólica” entre el retrato icónico de Olaya hecho por Gil de Castro en 1828 y el patronazgo de san José, figura del santoral que había adquirido una carga política innegable (Barriga, 2010). Era personificación del paternalismo, uno que se acentuaba en tiempos críticos.

35 Se respondió a este con la inclusión en la Guía peruana de los honores que el Congreso anterior le había otorgado (Ugarte del Pino, 1978, p. 222) 
yecto político y a su persona, murió Bolívar en 1830. Puede presumirse que no se viera la urgencia de plasmar una gloriosa muerte para él; ya contaba con un retrato icónico, el de Gil de Castro, y se había dictaminado realizar un monumento a su persona. Solo cuatro años después, ante un tablero político diferente, en el que un sector veía con otros ojos al Libertador y lo aproximaba a la imagen del padre de la patria, parecería haberse visto la necesidad de perfilar mejor la imagen del héroe y brindarle una muerte bella. No en vano la guerra iconográfica continuaba: Yáñez sería una pieza de ella.

\section{La muerte bella}

Cuando aún desconocía Horacio que tendría que luchar contra Curiacio, su gran amigo, le preguntó si, de morir por Roma, él lo lloraría y, antes de recibir la respuesta, advirtió: "Para un corazón noble esa muerte es maravillosa; la gloria que la sigue no permite las lágrimas y la recibiría bendiciendo mi suerte si Roma y su estado ganasen algo con mi sacrificio". Curiacio acotó: "Sin embargo, permitid que vuestros amigos la teman, una muerte tan bella, son ellos los únicos que han de llorar, porque la gloria es para vos y la pérdida para ellos. Vos os hacéis inmortal y ellos desdichados". Finalmente, Horacio sobrevivió, pero a costa de la vida de Curiacio y de matar a su propia hermana, Camila, quien le recriminó la muerte de su amado (Corneille, 1957, pp. 122-123).

Este sentido del deber, de la familia, de la muerte y de de-

276 fensa de la patria se observa siglos más tarde en el Estatuto Provisorio de San Martín, quien hace una severa exhortación: “Maldito sea entre los hijos de la Patria, el que resistiendo la justicia y olvidando su mismo interés, no esté dispuesto a ser americano, antes que padre, hijo, esposo o hermano!" (De la Puente, 1974, p. 372). Ofrecer la vida por la patria sería, entonces, una muerte como aquella de la que habla Curiacio, una muerte bella. El héroe tenía una muerte de este tipo. 
Bolívar, sin embargo, no había muerto por la patria, sino de tuberculosis y, aunque muchas bellas muertes de la literatura eran de enfermos de este mal, ¿cabía hablar de una muerte bella?

El término refiere al modelo de muerte que se observa especialmente en una Francia en la cual el proceso de laicización era avanzado en el siglo XVIII, y en la que los principios ilustrados encontraron plena vigencia. ${ }^{36}$ En ese sentido, conviene recordar que Lessing emprendió una cruzada por dejar en claro que los hombres de la Antigüedad no representaron a la muerte como un esqueleto, sino que consideraron inextricablemente unidos a Hypnos y Thanatos, hermanos gemelos e hijos de la Noche. Representaron a Thanatos como un joven de pies torcidos, quien apaga la luz de una antorcha, $y$ no como un ser repugnante y aterrador (1992, pp. 23 y 29). De allí que El genio de Francia entre la libertad y la muerte, de Jean Baptiste Regnault (1795, en el Museo Kunsthalle, Hamburgo), se haya considerado la representación del hombre libre, ilustrado, que da la espalda a la imagen barroca de la muerte (Vovelle, 1995, p. 11). La muerte perdía el dramatismo anterior y el hombre se iba reconciliando con ella, contemplada en su concepción natural, como parte del ciclo cósmico y destinada a todos los seres vivos. ${ }^{37} \mathrm{Su}$ expresión adecuada era, entonces, la iconografía de la escala de la vida o los estados de esta, a iniciarse en la cuna y concluir en la sepultura. La preocupación se enfocaba en todo caso, en la demografía. El énfasis era distinto.

La mortalidad como realidad asumida, al no ser una ruptura y no abrir a la persona al camino del sufrimiento, no

36 Véase Ariès (1987, pp. 341-394).

37 Esa continuidad se percibe en el Monumento fúnebre de Maria Cristina de Austria (iglesia Agustina, Viena), realizado por Antonio Cánova entre 1798 y 1805 . Véase Vovelle (1983, pp. 399 y 519). 
resultaba desagradable, sino que podía esconder, tras de sí, la belleza. Era el caso de las muertes románticas de la literatura, en las cuales el protagonista joven y bello enfermaba, languidecía y fallecía. El lecho del enfermo no era como lo había sido durante mucho tiempo: un lugar de lucha entre las fuerzas del bien y las del mal. De otro lado, como la creencia en el infierno decaía fuertemente (Ariés, 1987, p. 394), cabía pensar la muerte casi como un dulce sueño. Esta se secularizaba y los cementerios extramuros, tanto por razones de higiene y sanidad como por un cierto afán de alejar aquello que pudiera mostrar la efectiva corrupción del cuerpo, se imponían. También irrumpía un sentimiento desmesurado y tremendo por la pérdida de los seres queridos, que buscaba perennizar por diversas vías su recuerdo, y se relacionaba ya con el romanticismo. En el mundo hispanoamericano y en el Perú, el proceso se vivió con sus propias particularidades y tiempos; por ejemplo, no desapareció por completo la imagen del esqueleto.

La cambiante sensibilidad del siglo XVIII y el "buen gusto" habían llevado, empero, paulatinamente, a la modificación de los temas vinculados a la muerte; en general, puede decirse que fue suavizando sus expresiones y que el interés de la gente en la amenazadora muerte se fue retrayendo. Esto será más notorio en el siglo siguiente: la habitual muerte en forma de arquero no se encontrará ya, por ejemplo, en el túmulo del arzobispo González de la Reguera, atribuido a Matías Maestro. ${ }^{38}$

La pérdida de dramatismo en las representaciones de la muerte podía observarse, así mismo, en una iconografía que atraviesa todos los tiempos: la muerte del santo. En el siglo XVIII tardío, tendió a adquirir un tono diferente: en

38 De acuerdo con Estabridis (2007, p. 57), este consolidó la "ruptura estilística” respecto de los anteriores. 
la Muerte de san José, de José Cortés y Alcocer (1778, San Francisco, Lima), por ejemplo, los rasgos de la muerte y el dolor han desaparecido para dar paso a una suerte de éxtasis del agonizante. La muerte, entonces, además de buena sería bella. Lo percibe Isabel Cruz en la Muerte de santa Rosa, de Laureano Dávila (1780, Dominicas de Santiago), que la considera un preludio de la sensibilidad romántica (1998, p. 76). En ambos casos, la muerte resulta más secular, pero también más cercana a la muerte íntima, ideal, que la muerte romántica desplegará.

La muerte devenía, entonces, en un evento más secular desde el siglo XVIII, y la creación del cementerio y de la primera Junta de Beneficencia de Lima (1825) implicó un paulatino, pero cada vez más persistente desplazamiento del rol de la Iglesia en lo relativo a la muerte. Los tres cuarteles más antiguos del cementerio estaban dedicados, sin embargo, a la resurrección, a san José y a san Antonio, con lo cual se sintonizaba con las devociones mostradas por la sociedad en otros ámbitos. La laicización en proceso, y la aceptación de enterramientos extramuros y fuera de las iglesias mostraron en el Perú una resistencia "informal, silenciosa y subterránea" (Casalino, 1999, p. 379) por parte de la población, a la que se le debió demostrar que la Iglesia estaba de acuerdo con el cambio. De otro lado, se hizo concesiones. Así, la muerte había dejado de ser un asunto que competía solo al ámbito religioso, pero de manera distinta o, en todo caso, a diferente ritmo que en el Viejo Mundo. Si allí se estaba viviendo el tiempo de la muerte del otro y la muerte bella -la del héroe-, acá esta se hallaba aún cercana a la buena muerte. Se ha visto en el caso de la alegoría de Yánez.

Esta pintura hace pensar en las muertes con el enfermo en cama, acompańado de quienes lo asisten -en este caso, reemplazados por sus allegados que contemplan apenados, pero resignados-, y un rompimiento de gloria en el que se observa 
la subida apoteósica del santo al cielo, donde esperan agitados los habitantes del empíreo. Debe decirse que los pintores hispanoamericanos no solo asumieron los modelos religiosos para estos temas (Esteva-Grillet, 2011, p. 80), sino que los "préstamos" de lo religioso eran frecuentemente intencionales (Reyero, 2010, p. 72). En el lienzo de Yáñez, sin embargo, como en las bellas muertes, no hay presencia de demonios; tampoco se ve el alma saliendo del cuerpo ni la ascensión propiamente dicha, pero se sobreentiende y se ve anticipada por la de Sucre, quien ocupa un lugar central y cumple una suerte de rol mediador, como los santos intercesores. Así mismo, expresa la continuidad del proyecto, pues, como afirma Benedict Anderson, al decaer el sentimiento religioso y las certezas que este brindaba, urgía "una transformación secular de la fatalidad en continuidad, de la contingencia en significado" y ratificaba la consecución de la gloria al cabo de una vida fatigada y sacrificada por altos ideales (2016, p. 29).

Por otro lado, los viejos temas de la muerte del justo y de la muerte del pecador seguían estando presentes, al igual que los temas de postrimerías. El MALI guarda un par de acuarelas y témperas sobre papel de $38 \mathrm{~cm}$ x $28 \mathrm{~cm}$ (ca. 1832-1841) de Pancho Fierro, que Majluf considera pudieron ser bocetos para pintura mural y a las cuales otorga una combinación de sentido didáctico, moralizador y satírico (2016, p. 14), de lo que no suele estar exenta la temática desde antiguo. ${ }^{39}$ En ambas pinturas, los castigos del infierno guardan las formas tradicionales; sin embargo, no hay santos intercesores ni imágenes marianas, aunque sí ángeles. Además, la persona se encuentra frente a su responsabilidad, que lo hará acreedor de subir al cielo o caer en el infierno. Aunque se mantiene la oposición muerte del pecador-muerte del justo, es una ver-

39 Este aspecto se encuentra en las Danzas de la muerte medievales, por ejemplo. La muerte, al ser "igualadora", trastoca las estructuras y crea una suerte de "mundo al revés". 
sión más sencilla -con mínima presencia de la Iglesia; son las obras de misericordia las que conducen a la salvación-, más secular, didáctica, y cercana a la piedad ilustrada y cristológica. Se está ante temas tradicionales tratados con una sensibilidad distinta.

Yáñez inserta su discurso en este medio. Se trata de glorificar al héroe, como lo hicieron los pintores del Neoclasicismo y del Romanticismo, pero un Antoine-Jean Gros, para pintar las campañas y la gloria de Bonaparte, tuvo primero un David que le preparó el camino. Y este mismo, antes que su Napoleón cruzando los Alpes (1801), había realizado no solo el Juramento de los Horacios, sino también Los lictores llevando a Bruto sus dos hijos muertos (1789), y aquellos modelos de muerte ideal para los nuevos tiempos cuando pintó las muertes de Sócrates, Marat y del joven Joseph Bara. Esa preparación no se dio en el caso del Perú del XIX y, si incluso en obras clave sobre la muerte durante esos años en el Viejo Mundo se deja traslucir esa suerte de "contaminación" con lo religioso, no puede asombrar que acá sucediera lo mismo, y con más razón. No en vano se ha visto en la obra mencionada de Regnault la llama de Pentecostés sobre la cabeza de Mercurio; en La Libertad guiando al Pueblo de Eugene Delacroix (1830, Museo del Louvre), la "secularización de una iconografía pictórica cristiana” como la del Cristo Salvador; y en la Muerte de Marat, la alusión al martirio de Cristo y la Piedad del Vaticano, en el brazo caído del revolucionario (Rauch, 2000, p. 405), que recuerda al de Cristo en obras altamente representativas de la historia del arte. ${ }^{40}$

40 Un aspecto que debe considerarse es que las bellas muertes de Bara y Marat tenían como sustento la historia sobre la cual se establecían como modélicas; eran cuadros de historia. Como se indicó, en Perú, fueron escasos hasta los Funerales de Atahualpa, de Luis Montero. En este, no solo está presente la historia, sino también la muerte real -al modo que en La balsa de la medusa de Géricault o la Libertad guiando al pueblo de Delacroix-, 
La obra de Yánez, por lo tanto, tomando un tema histórico, contingente, pretendía la glorificación del genio y, para ello, apelaba a la alegoría. Sin embargo, en el caso de Bolívar, su personalidad y muerte no se habían acabado de perfilar para configurar el arquetipo de padre de la patria. La tensión contingencia-eternidad, difícil de enfrentar en la pintura de la muerte del héroe (Reyero, 2003), no estaba aún resuelta. Contaba, eso sí, con una característica importante para ser una muerte bella: haber sido prematura (Casalino, 2016, p. 33) y, por otro lado, con una base ya mencionada y subrayada en el diario de Révérend: la enfermedad a la que no le prestó suficiente cuidado por atender sus deberes patrióticos, la pobreza en la que murió al contar solo con una camisa raída para su entierro, el desagradecimiento y la deslealtad de aquellos a quienes había ayudado a alcanzar la libertad. Todo ello configuraba un martirio que el tiempo reivindicaría y acabaría anulando lo prosaico de su fallecimiento. Para el caso de Venezuela, Carolina Guerrero ha visto, por ejemplo, cómo en 1876, con el traslado de los restos de Bolívar al Panteón Nacional, ya se estaba en condiciones de congregar a los ciudadanos "en torno a la culpa histórica, suscitada ante el martirio del mesías republicano que expiró en soledad y ante la irrealización de su voluntad" (2006, p. 29). Sin embargo, ese camino todavía no se había recorrido en la década del treinta del siglo XIX en el Perú: Bolívar no era un héroe indiscutible para todos; no había nacido en territorio peruano; no había un cuerpo al cual enterrar, aunque fuera en un segundo entierro; y su política autoritaria le había granjeado muchos enemigos. ${ }^{41}$

con la representación de Atahualpa sobre la base de un cadáver verdadero (Majluf, 2004, p. 17).

41 Véase lo que decía sobre Bolívar El Duende de Buenos Aires. Reconocía que fue un héroe, y agregaba "pero cuando las virtudes de la guerra hicieron necesaria su cooperación en el Bajo Perú, se permitió actos de una arbitrariedad tan desmesurada, y de una inmoralidad tan compleja, 
Esto se percibió en las exequias realizadas en la catedral de Lima el 24 de marzo de 1831, presididas por el vicepresidente Antonio Gutiérrez de la Fuente. A pesar del lucido túmulo de gusto clásico en el que su retrato era atrapado por una muerte agazapada tras un paño, no hubo la habitual oración fúnebre. Esto se quiso justificar apelando al poco tiempo que hubo y, como anunció en su edición del 5 de abril de 1831 el Mercurio Peruano - periódico con una línea favorable al Libertador-, a las épocas que se vivían, "borrascosas", y "a cuya sombra se han fomentado pasiones de diverso género". Si se toma en cuenta que el funeral era un "instrumento político" en el cual se fijaban "ideas fuerza" (McEvoy, 2006, pp. XVIXVII), se intuye el peso de esta carencia. ${ }^{42}$

En la segunda mitad del siglo XIX, con la llegada de los pintores locales formados en Italia y Francia con los románticos; con la fotografía; con los retratos en miniatura y postmortem; con los entierros en nichos; con las necrologías y los mausoleos familiares; y con héroes como Necochea y La Mar, constituidos en motivo de orgullo, ya la situación sería distinta.

que la opinión empezó a reusarle un tributo, que hasta entonces había rendido a su reputación [...]. ¿ Y cómo ha satisfecho el general Bolívar la confianza de los peruanos, la gratitud de los de Bolivia y las esperanzas de los liberales? Proclamando la liberalidad, y procediendo como absoluto; hablando siempre de la soberanía del pueblo, y destruyéndola; invocando siempre la justicia, y persiguiendo siempre, y proscribiendo, dimitiendo a cada paso una autoridad temporaria, y electiva, y procurando una perpetua y hereditaria [...] la disolución del Congreso del Perú de 1826, el mayor delito de lesa nación con que ha podido manchar sus glorias el general Bolívar. Mandatarios dignos del pueblo, deseosos de ver a un país libre de la influencia extranjera, levantan la voz para hacerse oír, y una calumnia atroz de anarquismo se deja caer sobre ellos, y desaparecen de su puesto" (Ensayo sobre la conducta del general Bolivar, 1826, pp. 9-10).

42 Carlos Gálvez encuentra que se da la concreción a la idea del héroe republicano en el sermón fúnebre de las ceremonias de repatriación de los restos de La Mar, el año 1847 (2012, p. 160). 
Los usos y costumbres anteriores eran severamente criticados en aras de la modernidad, que celebraba las tarjetas de "filetes negros", el "refinamiento" y los signos de "decencia" y "civilización" frente a las costumbres del "vulgo", de la "plebe", que aún mantenía celebraciones en torno a la muerte y al duelo que podían ser consideradas "ridículas" (Fuentes, 1985 [1867], pp. 58 y 132-133). ${ }^{43}$ Para entonces, la sociedad se había reconciliado con la figura de Bolívar perfilada y había dejado de lado todo aquello que pudiera ser repudiable. Una escultura de 1859 como la de Tadolini, discípulo de Cánova, podía sugerir, quizás, más la muerte bella que el mismo lienzo de Yáńez. No en vano todos los monumentos son memoria de la muerte (Castrillón, 1991, p. 325).

Finalmente, el contraste entre las exequias de 1831 y la conmemoración del centenario de la muerte es claro y grandilocuente: Bolívar era el padre de la patria, el "más grande y glorioso hombre de América", a quien "calumniaron" y "vilipendiaron" (Villa y Martínez, 1939). Había adquirido su definitivo perfil y no solo contaba ya con la comunidad de culto, sino también con el reconocimiento oficial y la legitimación social que Carlota Casalino ha considerado como esenciales para la consagración del héroe (2016, p. 103).

\section{A modo de conclusión}

Con la independencia y la ruptura que supuso en distintos ámbitos, la necesidad de dejar atrás lo que se consideró oscu-

284 rantismo y cultura "gótica" llevó a que se planteara el clasicismo como lenguaje de la nueva era. Este, al ser claro y preciso, debía contribuir a gestar la sociedad republicana. Lo iconográfico cobraba un lugar primordial y así lo entendieron San Martín y Bolívar. José Gil de Castro constituyó, en ese punto,

43 Si décadas antes Vidaurre había sido crítico con los usos y costumbres en torno a la muerte, Manuel A. Fuentes fue ácido con ellos. 
una pieza fundamental para asentar a la élite militar y política, y un pilar para la creación de íconos republicanos. Estos resultaban imprescindibles para llamar a la acción, a la defensa de la patria, y a la lucha por el nuevo orden y civilidad.

Si la iconografía de la muerte había ocupado un lugar central en las sociedades de antiguo régimen, en tiempos de tránsito no podía quedar desplazada. Así como la muerte del soberano aglutinaba a la sociedad y reafirmaba los lazos con el régimen, la del héroe también debía hacerlo. Una muerte heroica suponía la muerte por la patria, que podía ser en batalla o por ejecución de parte del enemigo. Constituía así una muerte bella, a la cual cabía aspirar para alcanzar la gloria y, de este modo, la inmortalidad. Simón Bolívar, quien llegó al Perú premunido de aires napoleónicos y conocimiento del mundo clásico, rodeado de una aureola de magnificencia, estaba llamado a ser el héroe de la independencia por excelencia. Murió, sin embargo, tempranamente, enfermo, en cama y en momentos desfavorables para su actuación política en los países que había contribuido a liberar. Frente a la muerte de un mártir de la república como José Olaya -quien fuera fusilado, con lo que su muerte adquiría el carácter de bella, y cuya figura quedaba inmortalizada en términos fácilmente comprensibles por la pintura que Gil de Castro hizo de él-, la muerte real de Simón Bolívar debía adquirir rasgos reveladores de su trascendencia en la lucha por la libertad americana y memorables para la comunidad imaginada. Así, años después de su fallecimiento y con vientos más favorables para su imagen, José Anselmo Yáñez convirtió la muerte real del líder -poco cercana a una ideal- en una muerte bella. Para ello, la alegoría era un magnífico instrumento.

Lo era no solo porque permitía fijar símbolos y dejar de lado todo aquello opuesto a la glorificación y dar un mensaje directo, sin lugar a matices, sino porque permitió crear equivalencias con modelos de muerte que ya eran conocidos de 
antemano: la buena muerte y la muerte del santo. Esto debe alertar sobre la necesidad de emplear "con pinzas" los términos y modelos que han sido pensados para otras realidades, y analizar cómo y sobre qué terreno preexistente actúan -si lo hacen- así en el plano de la sensibilidad en torno a la muerte como en el de la retórica visual. Puede decirse, entonces, que la hibridación observada en la pintura se asemeja en mucho a la que se da en el plano de la bella muerte. No se construye sobre una tabla rasa, sino que se escoge, matiza, modula de acuerdo con los propios tiempos y necesidades. La muerte se constituye en un evento mucho más secular, pero los valores libertarios y republicanos se sacralizan -tal como sucedió en la Francia revolucionaria-: si una vida acorde con los principios cristianos permitía acceder al cielo, el Olimpo se ofrecía metafóricamente a quien llevara una vida acorde con los ideales republicanos. Si moría por ellos, se convertía en mártir.

En años de guerra, enfermedad, bandolerismo, juicios sumarios y ejecuciones en términos distintos a los virreinales, la consideración de la muerte, de sus usos y costumbres, y la sensibilidad en torno a ella se estaban modificando, así como la idea de sociedad, sus principios rectores y lo que se esperaba del gobierno. En este mundo actuó Bolívar y, en este contexto, Yáńez pintó la alegoría de su muerte, con un claro sentido político. En la medida en que eran años extremadamente convulsos, puede pensarse que, para quienes añoraban los tiempos de orden y de un ejecutivo fuerte, esta debía reivindicar y enaltecer la imagen de Bolívar, que encarnaba aquello que se había perdido. Solo cabe especular si una mejor comprensión de su muerte bella no se hubiera dado, quizás, hacia mediados de siglo, cuando la distancia de la Constitución Vitalicia y del accionar de sus últimos años hubiera permitido que su imagen se acabara de perfilar como la del padre de la independencia y cuando se hubiera dado en la pintura ese "cambio y ruptura solo comparable a la conquista", del que habla Natalia Majluf para la segunda mitad del siglo XIX. 


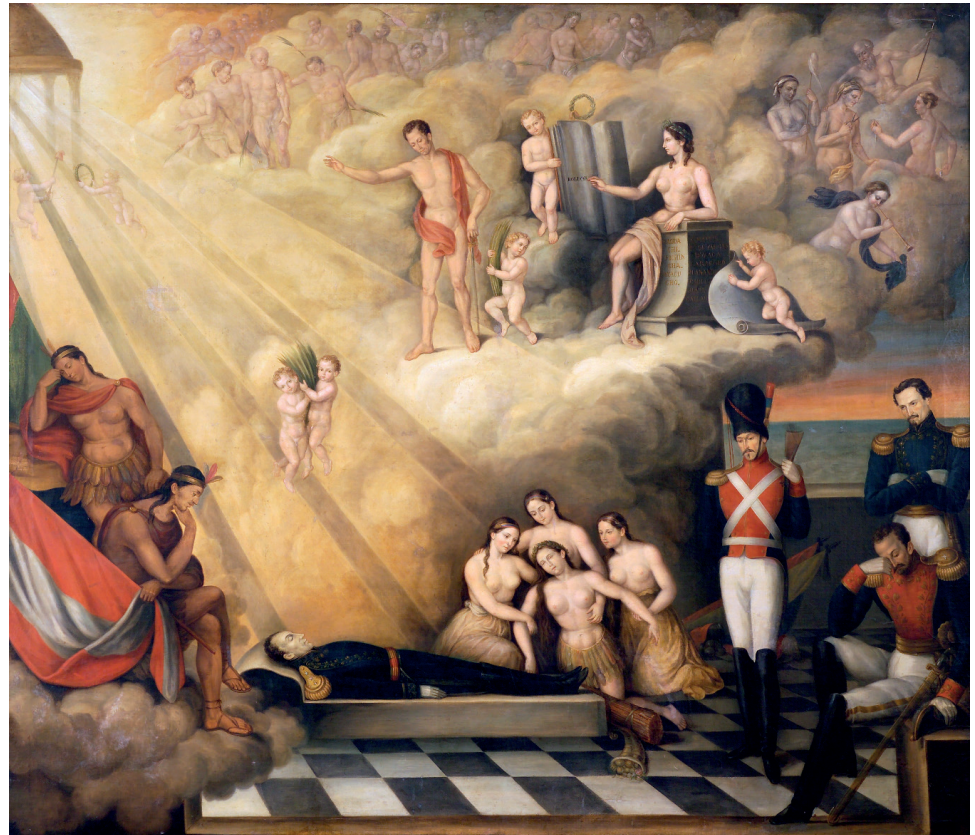

Anónimo (siglo XIX). Alegoría a la muerte de Simón Bolivar. Estilo académico. Óleo sobre tela, $168 \mathrm{~cm}$ x $195 \mathrm{~cm}$.

Agradecimiento: Museo Nacional de Arqueología Antropología e Historia del Perú (MNAAHP).

Fotografía: Daniel Giannoni S. 


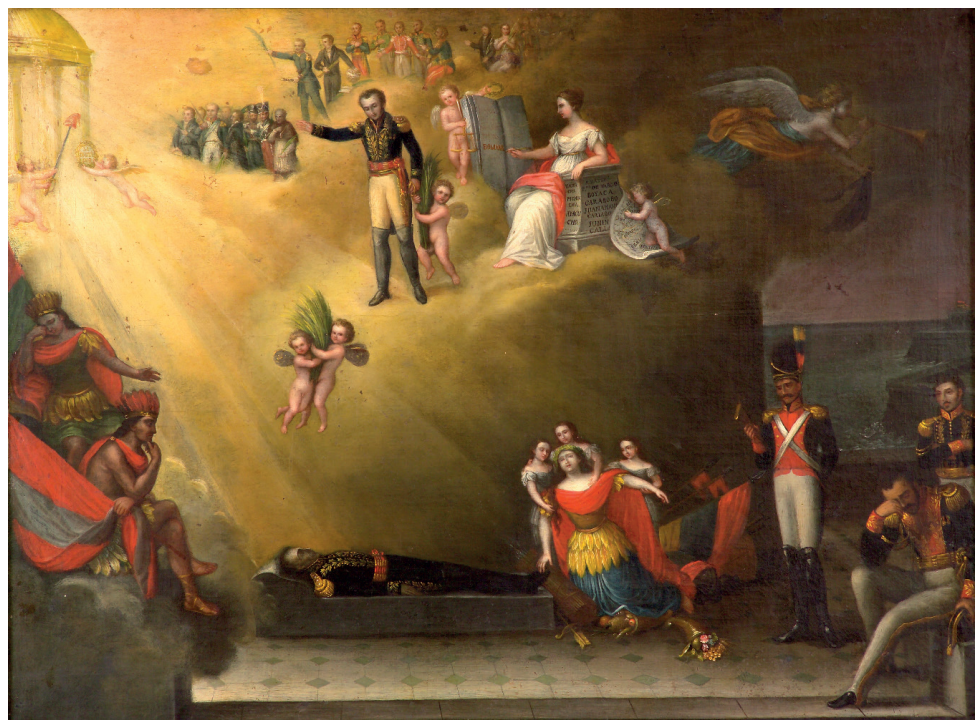

288

José Yánez Pastor (1834). Alegoría a la muerte de Simón Bolivar.

Óleo sobre tela, $64.5 \mathrm{~cm}$ x $81 \mathrm{~cm}$.

Agradecimiento: Museo Nacional de Arqueología Antropología e Historia del Perú (MNAAHP).

Fotografía: Daniel Giannoni S. 
Recibido: 19 de agosto de 2020

Aprobado: 18 de noviembre de 2020

\section{Fuentes y bibliografía}

\section{Fuentes primarias}

Bolívar, S.

(s. f.) Relación de la vida del general. Compañía Nacional Anónima de Teléfonos de Venezuela.

Corneille, P.

(1957) "Horacio". En Teatro trágico. Traducción, prólogo y notas por Ignacio Gallego. Talleres Gráficos Agustín Núñez

Ensayo sobre la conducta del general Bolivar. Reimpreso, de los números 11, 13 y 14 del Duende de Buenos Aires.

(1826) Imprenta de la Independencia.

El Comercio

(1843, 22 de abril). "Falso anuncio". El Comercio (Perú), p. 5.

El Comercio.

(1841, 9 de diciembre). “José Yáñez retratista al óleo”. El Comercio (Perú), p. 1.

Fuentes, M. A.

(1985 [1867]) Lima. Apuntes históricos, descriptivos, estadisticos y de costumbres. París: Librería de Fermin Didot Hermanos e Hijos. Ed. facs. Lima: Banco Industrial del Perú.

Gutiérrez, E.

Esfuerzos y resistencias. 1912-1921. Memoria del director del Museo de Historia Nacional, Tomo 1. Taller Tipográfico del Museo. 
Lessing, G. E.

(1992 [1769]) "Cómo los antiguos se imaginaban a la muerte". En A. Andreu (Ed.), La Ilustración y la muerte: dos tratados (pp. 1-52). Consejo Superior de Investigaciones Científicas y Editorial Debate S. A.

Mathison, G. F.

(1971) "Residencia en Lima entre abril y mayo de 1822". En E. Núñez (Ed.), Relaciones de viajeros, vol. 1 (pp. 269-318). CDIP, tomo XXVII. Comisión Nacional del Sesquicentenario de la Independencia del Perú.

Monteagudo, J. B.

(1974) "Diálogo de Atahualpa y Fernando VII en los Campos Elíseos (Chuquisaca, 1808)”. En G. Ugarte (Ed.), El teatro en la independencia, vol. 1 (pp. 251261), CDIP, tomo XXV. Comisión Nacional del Sesquicentenario de la Independencia del Perú.

Puente J. A. de la (Ed.).

(1974) Obra gubernativa y epistolario de San Martín, vol. 1, CDIP, tomo XIII. Comisión Nacional del Sesquicentenario de la Independencia del Perú.

Révérend, A. P.

(1866) La última enfermedad, los últimos momentos y los funerales de Simón Bolivar, Libertador de Colombia y del Perú, por su médico de cabecera. Imprenta HispanoAmericana de Cosson y Compañía.

290 Romá y Rosell, F.

(1768) Las señales de la felicidad de España y medios de hacerlas eficaces. Imprenta de don Antonio Muñoz del Valle.

Salvin, H. S.

(1973) "Diario del Perú". En E. Núñez (Ed.), Relaciones de viajeros, vol. 4 (pp. 1-128), CDIP, tomo XXVII. Co- 
misión Nacional del Sesquicentenario de la Independencia del Perú.

Sociedad Bolivariana de Venezuela.

(1964) Escritos del Libertador, vol. 1, Introducción General. Editorial Arte.

Stevenson, S. B.

(1971)

"Memorias sobre las campañas de San Martín y Cochrane en el Perú”. En E. Núñez (Ed.), Relaciones de viajeros, vol. 3, (pp. 73-228), CDIP, tomo XXVII. Comisión Nacional del Sesquicentenario de la Independencia del Perú.

Tauro, A. (Ed.).

(1973) Periódicos, vol. 1, CDIP, tomo XXIII. Comisión Nacional del Sesquicentenario de la Independencia del Perú.

Thomas, J.

(2019) Diario de viaje del general O'Higgins en la campaña de Ayacucho. En J. Ortiz y C. Guerrero (Eds.). Sociedad Bolivariana del Perú.

Villa y Martínez, J. C.

(1930, 22 de diciembre) "Bolívar en el centenario de su muerte". El Comercio (Lima).

\section{Bibliografía}

Aljovín de Losada, C.

(2000) Caudillos y constituciones. Perú: 1821-1845. Fondo de Cultura Económica, Pontificia Universidad Católica del Perú e Instituto Riva-Agüero.

Anderson, B.

(2016)

Comunidades imaginadas. Reflexiones sobre el origen y la difusión del nacionalismo. Fondo de Cultura Económica. 
Ariès, P.

(1987) El hombre ante la muerte. Taurus.

Arocha, M.

Iconografía ecuatoriana del Libertador. Librería e Imp. Romero.

Barriga, I.

(2010) Patrocinio, monarquía y poder: el glorioso patriarca señor san Joseph en el Perú virreinal. Instituto RivaAgüero.

Basadre, J.

(1968) Historia de la República del Perú, tomos I, II y III, 6a ed. Editorial Universitaria.

Basadre, J.

(2015) "La serie de probabilidades dentro de la emancipación peruana”. En C. Contreras y L. M. Glave (Eds.), La independencia del Perú: ¿concedida, conseguida, concebida? (pp. 75-135). Instituto de Estudios Peruanos.

Bolívar, S.

(1951 [22 abril 1829]) "Carta a Estanislao Vergara". En Itinerario de una vida admirable: Simón Bolivar. Embajada de Venezuela.

Boulton, A.

292
(1956)
Los retratos de Bolivar. [s. e.]

Casalino, C.

(1999) La muerte en Lima en el siglo XIX: una aproximación demográfica, politica, social y cultural. (Tesis para optar el grado de magíster en Historia). Pontificia Universidad Católica del Perú, Escuela de Posgrado, Lima. 
Casalino, C.

(2008) Los héroes patrios y la construcción del Estado-Nación en el Perú (siglos XIX y XX). (Tesis para optar el grado académico de doctor en historia). Universidad $\mathrm{Na}$ cional Mayor de San Marcos, Lima.

Casalino, C. (2016)

"Comunidad de culto y construcción del héroe: la rebelión de Tacna y Francisco de Zela, 1811-1911". En A. Loayza (Ed.), La independencia peruana como representación. Historiografía, conmemoración y escultura pública (pp. 103-134). Instituto de Estudios Peruanos.

Castrillón, A.

(1991) "Escultura monumental y funeraria en Lima". En J. A. Lavalle (Ed.), Escultura en el Perú (pp. 325-385). Banco de Crédito del Perú

Chartier, R.

(1995) Espacio público, crítica y desacralización en el siglo XVIII. Los orígenes culturales de la Revolución francesa. Gedisa.

Chicangana-Bayona, Y. A.

(2010) "La India de la libertad: de las alegorías de América a las alegorías de la patria”. Argos, 27 (53), 145163. http://ve.scielo.org/scielo.php?pid=S0254$16372010000200007 \&$ script=sci_arttext.

Cruz de Amenábar, I.

La muerte. Transfiguración de la vida. Ediciones Universidad Católica de Chile.

Estabridis, R. (2007) "Iconografía del poder en el epílogo virreinal: el retrato y la fiesta”. Illapa, 4, 49-62. 
Esteva-Grillet, R.

(2011) "La muerte del héroe en la pintura colombo-venezolana durante el siglo XIX”. SituArte, 6 (10), 79-88.

Foucault, M.

(2004) Vigilar y castigar. Nacimiento de la prisión. Siglo Veintiuno Editores.

Gálvez, C.

(2012)

"El rey, la Constitución y la patria. Prédica y cultura política en el Perú durante la primera mitad del siglo XIX”. En C. McEvoy, M. Novoa y E. Palti (Eds.), En el nudo del imperio. Independencia y democracia en el Perú (pp. 151-170). Instituto de Estudios Peruanos e Instituto Francés de Estudios Andinos.

Guerrero, C. (2006)

"Los funerales de Simón Bolívar: fundación de un mito en la construcción del patriotismo republicano, 1830, 1842 y 1876”. En C. McEvoy (Ed.), Funerales republicanos en América del Sur: tradición, ritual y nación (pp. 3-30). Centro de Estudios Bicentenario.

Holguín, O.

(1998) Tiempos de infancia y bohemia. Ricardo Palma (18331860). Pontificia Universidad Católica del Perú.

Hunt, L. (2017)

"La vida privada durante la Revolución Francesa". En Ph. Ariès y G. Duby (Dirs.), Historia de la vida privada, t. IV (pp.23-51). De la Revolución Francesa a la Primera Guerra Mundial. Taurus.

Kusunoki, R.

(2006) "Matías Maestro, José del Pozo y el arte en Lima a inicios del siglo XIX". Fronteras de la Historia, 11, 183-209. 
Kusunoki, R.

(2009) "Mercados libres y artes liberales: el tránsito de las tradiciones pictóricas locales al academicismo en Lima (1837-1842)”. Illapa, 6, 47-60.

Kusunoki, R.

(2010) "La reina de las artes": pintura y cultura letrada en Lima (1750-1800). Illapa, 7, 51-61.

Kusunoki, R. y Wuffarden, L. E.

(2014) "Un retratista limeño en tiempos de la Independencia”. En N. Majluf (Ed.), José Gil de Castro. Pintor de libertadores (pp. 34-51). Museo de Arte de Lima.

Lynch, J.

(2019) Simón Bolivar. Editorial Planeta.

Majluf, N.

"Más allá del texto: Francisco Laso y el fracaso de la esfera pública". http://www.esteticas.unam.mx/edartedal/PDF/Buenosaires/complets/Majluf-buenosaires.pdf.

Majluf, N.

(1993)

"Entre pasatiempo y herramienta artesanal: aspectos de la enseñanza del dibujo en el XIX”. Sequilao, 2 (3), 32-43.

Majluf, N. (1994)

Escultura y espacio público: Lima 1850-1879. Instituto de Estudios Peruanos.

Majluf, N.

(2004)

"El rostro del Inca. Raza y representación en Los funerales de Atahualpa de Luis Montero". Illapa, 1, 1128. 
Majluf, N.

(2013)

"De cómo reemplazar a un rey: retrato, visualidad y poder en la crisis de la independencia (1808-1830)". Histórica, 37, 73-108.

Majluf, N.

(2014) En busca de José Gil de Castro. Rastros de una (auto) biografía. En N. Majluf (Ed.), José Gil de Castro. Pintor de libertadores (pp. 2-19). Museo de Arte de Lima.

Majluf, N. (2018)

"Placeless monuments. Portraiture, History, and Sites of Memory in South American Independence". En J. Rivas, (Ed.), Circulation: Movement of Ideas, Art, and People in Spanish America (pp. 190-212). Denver Art Museum.

Majluf, N. y Wuffarden, L. E.

(2004) "Entre la ruptura y la continuidad". En L. E. Wuffarden, J. García Bryce, N. Majluf, J. Villacorta y C. Trivelli, Enciclopedia Temática del Perú. Arte y Arquitectura, tomo XV. El Comercio.

Majluf, N. y Wuffarden, L. E.

(2015) "El siglo XIX: entre tradición y modernidad". En N. Majluf (Ed.), Arte republicano (pp. 1-59). Museo de Arte de Lima.

296

McEvoy, C. (2006)

"El funeral de Estado y la invención de la tradición republicana en América del Sur, 1832-1896”. En C. McEvoy (Ed.), Funerales republicanos de América del Sur: tradición, ritual y nación, 1832-1896 (pp. XIXXXIII). Centro de Estudios Centenario.

O'Phelan, S.

"Vida material y entorno social del Palacio de la Magdalena en tiempos de Bolívar". En S. O’Phelan 
(Ed.), La quinta de los Libertadores [Catálogo] (pp. 29-45). Ministerio de Cultura y Museo Nacional de Arqueología, Antropología e Historia del Perú.

O'Phelan, S. (2019)

Simón Bolivar y la conclusión de la independencia en el suelo de los incas. Fondo Editorial del Congreso del Perú.

Plaza, L. de la, Martínez J. M. y Vaquero, J. I.

(2018) Guia para identificar los personajes de la mitología clásica. Cátedra.

Quesada, V.

(2011)

"Luis Montero. Pintor peruano de la Academia de Florencia (1867)". En N. Majluf (Ed.), Luis Montero. Los funerales de Atahualpa (pp. 2-23). Museo de Arte de Lima.

Rauch, A. (2000)

"Neoclasicismo y Romanticismo: la pintura europea entre dos revoluciones". En R. Toman (Ed.), Neoclasicismo y Romanticismo. Arquitectura, escultura, pintura, dibujo (pp. 318-479). Könemann.

Reyero, C.

(2003)

"SSalvemos al cadáver! Inmortalidad y contingencia del héroe en la plástica española del siglo XX”. En M. Chust y V. Mínguez (Eds.), La construcción del héroe en España y México (1789-1847) (pp. 175-209). Universitat de Valencia.

Reyero, C.

(2010) Alegoria, nación y libertad. El Olimpo constitucional de 1812. Siglo XXI.

Rizo Patrón, P.

(2012) "Una aristocracia ambivalente: Torre Tagle y sus pares ante la independencia del Perú”. En C. Mc Evoy, 
M. Novoa y E. Palt (Eds.), En el nudo del Imperio. Independencia y democracia en el Perú (pp. 295-313). Instituto de Estudios Peruanos e Instituto Francés de Estudios Andinos.

Sáez, A.

(2013) Simón Bolivar. El Libertador y su mito. Marcial Pons.

Sánchez, S.

(2001)

"Clima, hambre y enfermedad en Lima durante la guerra independentista (1817-1826)". En S. O'Phelan (Comp.), La independencia del Perú. De los Borbones a Bolivar (pp. 237-263). Instituto RivaAgüero y Pontificia Universidad Católica del Perú.

Sánchez, S.

"Ejército, epidemias y alimentación en las guerras de la independencia”. En S. O'Phelan (Ed.), La quinta de los Libertadores [Catálogo] (pp. 139-151). Ministerio de Cultura y Museo Nacional de Arqueología, Antropología e Historia del Perú.

Soboul, A.

La Revolución francesa. Tecnos.

Torres, B.

(2001) “Amor y muerte en el romanticismo". En B. Torres (Dir.), Amor y muerte en el romanticismo (pp. 13-77). Ministerio de Educación, Cultura y Deporte.

Ugarte del Pino, J. V.

(1978) Historia de las Constituciones del Perú. Andina S. A.

Vallejo, P.

(2011) La niebla y la montaña: tratado sobre el teatro ecuatoriano desde sus orígenes. Palibrio. 
Vanegas, C.

(2012) Iconografía de Bolívar: revisión historiográfica. Ensayos. Historia y teoría del arte, 22, 112-134.

Vargas Ugarte, R.

(1971) Historia general del Perú, tomo VII. La república (1825-1833). Carlos Milla Batres.

Vidal, A., Quispe, E. y Véliz, T.

(2015) Catálogo. En O’Phelan (Ed.), La quinta de los Libertadores [Catálogo] (pp.175-236). Ministerio de Cultura, y Museo Nacional de Arqueología, Antropología e Historia del Perú.

Villa y Martínez, J. C.

(1930, 22 de diciembre) Bolívar en el Centenario de su muerte. El Comercio.

Vovelle, M.

(1983) La mort et l'Occident de 1300 a nos jours. Gallimard.

Vovelle, M.

(1995) Introducción. En M. Vovelle et ál., El hombre de la Ilustración (pp. 9-39). Alianza Editorial.

Wuffarden, L. E.

(2001) "Gil de Castro, el pintor de los Libertadores". En S. O'Phelan (Comp.), La independencia del Perú. De los Borbones a Bolivar (pp. 455-508). Instituto RivaAgüero.

Wuffarden, L. E.

(2006) "Avatares del bello ideal, modernismo clasicista versus tradiciones barrocas en Lima 1750-1825". En R. Mujica Pinilla (Coord.), Visión y simbolos del virreinato criollo a la república peruana (pp. 113-159). Fondo Editorial BCP. 